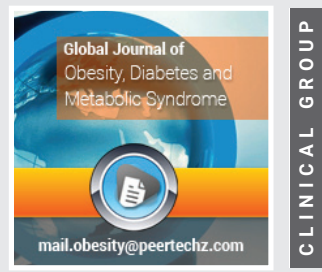

\section{Obesity, Diabetes, and Metabolic Syndrome}

\author{
Ghada Welwel*
}

University of Paris, France
Received: 12 March, 2020

Accepted: 05 June, 2020

Published: 30 June, 2020

*Corresponding author: Ghada Welwel, University of Paris, France, Tel: +96550541004;

E-mail:welwel.ghada@gmail.com

https://www.peertechz.com

Check for updates
In the contemporary society, there are various health factors that affect people, both the elderly and the young population based on their environment and the interconnected risk factors. Based on that, it is necessary to understand and comprehend that metabolic syndrome also known as (Mets) involves a combination of risk factors for glucose intolerance, insulin resistance, obesity, dyslipidemia, as well as hypertension [1]. In most cases, the syndrome is associated with emergence and development of kidney disease, diabetes, increased mortality rate, and cardiovascular disease. It is also important to understand that obesity involves excess corporal adiposity. Notably, diabetes occurs or takes place when the blood sugar level is too high [1]. The blood sugar level is often the main source of energy and it originates from the food that one eats. Based on the interconnected aspects, it is essential to understand some of the related aspects concerning disability, obesity, and metabolic syndrome.

In the opinion of most researchers, it has been evident that most of the technicians and clinicians use the body weight as one of the indirect measures of the magnitude and degree of the adiposity in relation to obesity [2]. Some of the causes of diabetes are metabolic, behavioral, and genetic influences on the body weight. Therefore, managing diabetes requires the understanding of elements relating to body weight [3]. This can also help in conducting research relating to obesity and body weight [3]. With regard to the impact of genetic factors in the development of Obesity, Diabetes, and Metabolic Syndrome, it is important to understand that Obesity can cause metabolic disturbances, which in turn causes other factors such as metabolic syndrome [2].

On the other hand, diabetes has been known to cause deaths among various people in both the developed and the developing nations due to the metabolic syndrome and other interconnected risk factors. For instance, in United States, about 30.2 million people are diagnosed with diabetes and the figure represents about $28 \%$ of the total population [4]]. Without necessary and needed management, diabetes can lead to rise and build up of unwanted sugar in the blood. Consequently, some of the complications may be heart diseases, and stroke [4]. It is also important to understand that before trying to only consider the aspect of being overweight as the cause of diabetes [4]. It is essential to note that some diabetic conditions may be present from childhood; hence managing the situation requires the understanding of the historical backgrounds. Type 1 diabetes takes place when one's body cannot produce the needed amount of insulin [5].

Another health condition that needs to be understood is metabolic syndrome and it involves many interconnected health risk factors such as excess body fat, high blood sugar, abnormal cholesterols, and increased blood pressures [6]. The syndrome is currently becoming common in various places including countries such as Australia and United States, as well as the developing countries [1]. If one has the metabolic syndrome, they may take some measures relating to aggressive lifestyle changes [6]. This may help in mitigating some of the serious health problems that may arise from the situation. It is also important to comprehend that the interconnected risk factors relating to metabolic syndrome are age, obesity, diabetes ethnicity, as well as other diseases such as liver disease, and sleep apnea [6].

In conclusion, diabetes occurs or takes place when the blood sugar level is too high. The blood sugar level is often the main source of energy and it originates from the food that one eats. On the other hand, diabetes has been known to cause deaths among various people in both the developed and the developing nations.

\section{References}

1. Aye M (2014) Metabolic Syndrome (MetS). Journal Of Metabolic Syndrome 3: 4. Link: https://bit.ly/3gXmVZy

2. Bell C (2017) The Epigenomic Analysis of Human Obesity. Obesity 25: 14711481. Link: https://bit.ly/2Mt9q5U 
3. Heindel J, Schug T (2013) The Perfect Storm for Obesity. Obesity 21: 10791080. Link: https://bit.ly/3gZmCxa

4. Leslie R (2013) Diabetes. Manson Pub. Link: https://bit.ly/2UdfJPo
5. Shepherd M (2014) Monogenic diabetes and the role of the diabetes nurse European Diabetes Nursing 11: 23-28. Link: https://bit.ly/3eTTi9M

6. Lin G (2013) C-Reactive Protein, Metabolic Syndrome and Cardiovascular Disease. Journal Of Metabolic Syndrome 01.
Discover a bigger Impact and Visibility of your article publication with

\section{Peertechz Publications}

\section{Highlights}

* Signatory publisher of ORCID

* Signatory Publisher of DORA (San Francisco Declaration on Research Assessment)

* Articles archived in worlds' renowned service providers such as Portico, CNKI, AGRIS, TDNet, Base (Bielefeld University Library), CrossRef, Scilit, J-Gate etc.

* Journals indexed in ICMJE, SHERPA/ROMEO, Google Scholar etc.

* OAI-PMH (Open Archives Initiative Protocol for Metadata Harvesting)

* Dedicated Editorial Board for every journal

* Accurate and rapid peer-review process

* Increased citations of published articles through promotions

- Reduced timeline for article publication

Submit your articles and experience a new surge in publication services (https://www.peertechz.com/submission).

Peertechz journals wishes everlasting success in your every endeavours.

Copyright: $\odot 2020$ Welwel G. This is an open-access article distributed under the terms of the Creative Commons Attribution License, which permits unrestricted use, distribution, and reproduction in any medium, provided the original author and source are credited. 